\title{
Onset and Pattern of Deformity in Leprosy
}

\author{
D) M. J. MALLAC** \\ St. Cergue, Vaud, Switzerland
}

\section{INTRODUCTION}

Leprosy, one of the oldest afflictions of man, is still the object of ignorance and prejudice. Its social stigma originates from fear, primitive, rational or religious as Edwards (1964) pointed out, and the opprobrium attached to it is largely emotional. Ever since the discovery of Hansen's bacillus (Mycobacterium leprae) in 1872 , no acepted method of in vitro cultivation has been reported. The epidemiology of the disease is still largely unknown; its mortality is low; its classification disputed; the evolution of its clinical features and its pathology not fully understood.

The long duration of leprosy, its uncertain incubation period, the normal life-span of its various clinical types without reaction, do confer on the disease a rather special status among chronic infections. In fact, as Skinsnes (1965) rightly observed, 'Leprosy is unique. It is unique in the peculiarly intense reaction it has called forth in diverse societies. It is also unique in the complex of immunity and pathology which gives it its identity'.

No other disease indeed entails such human and social consequences in the community where it is prevalent, as expressed by so much distress and unhappiness to the patients and their families, whose numbers run into millions. Because of the slow action of anti-leprosy therapy, hence the long duration of treatment, the non-discovery as yet of new and more effective drugs and/or immunizing agents to provide a short-cut to leprosy control, results are not spectacular, and indeed cannot be so in a disease with such characteristics and disposing of such limited tools.

Yet deformity is the overriding feature of leprosy: it not only throws an ever increasing burden upon society, by reducing the patient's capacity for work, but is also responsible for the dread and special horror with which the disease is still regarded. In both instances, its relentless crippling is associated with a progress- ing loss of function, and this cloes carry more weight when, as is tragically the case, resources are limited and facilities for the care of the disabled are wanting in general. Furthermore, the handicapped leprosy patients, in the absence of any other occupation, become mendicants as is commonly seen in some South East Asia countries. Their growing numbers do represent a loss to the community in terms of productive labour.

The problem of deformity in leprosy is of such magnitude and growing importance that it will retain our sole attention here, for apart from the clinical aspects, it is obvious that in many developing countries where the disease is endemic, the loss of man power does hamper the rise of economic level, the standard of living and the education of the community.

Brand (1960) commented realistically as follows: 'The disease of leprosy is not itself directly responsible for most of the deformities that are attributed to it. It often removes the sensation of pain, and so allows the patient to damage and to deform himself. The more closely one studies the natural history of deformity, the more one finds that secondary changes and sometimes almost incidental damage and infection have been the cause of most of the mutilation from which these patients suffer'.

One is thus led to the realization that more light is needed into the problem and, with this in mind, the present study arises out of an experience of some io years in the field, in West Africa, Burma and India, covering thousands of patients among whom a detailed study of 700 was made in relation to the onset and the clinical pattern of deformity of the extremities produced by leprosy.

It is difficult to overestimate the significance of deformity as part and parcel of a disease which has come to occupy the unique position that it has throughout the centuries. What is

\footnotetext{
* At present WHO Consultant Leprologist, India.
}

Onset and Pattern of Deformity 
the size of the problem? Estimates of the prevalence of leprosy itself vary widely, yet the latest consensus of opinion is that there are about 20 million patients throughout the world. The following tables will give an idea.
How many of these are disabled and/or deformed by the disease? Again, estimates vary and the following tables will provide some figures that would allow an appraisal of the socio-economical implications of leprosy:

T AB LE I

Estimates of the World Prevalence of Leprosy

\begin{tabular}{lll}
\hline Author & Tear & Estimates \\
\hline Chaussinand & I $95^{\circ}$ & 5 million cases \\
International Congress of Leprology, Madrid & I 953 & 9 million \\
Doull & I $95^{6}$ & 3 to I 2 million \\
International Congress of Leprology, Tokyo & I $95^{8}$ & I 5 million \\
Guinto & I 960 & 2 million registered cases \\
Dharmendra & I 960 & 5 million \\
Gay Prieto & I 96 I & Io million \\
International Congress of Leprology, Rio de Janeiro & I 963 & 20 million
\end{tabular}

TABLE 2

Registered, Estimated and Treated Patients in the World*

\begin{tabular}{|c|c|c|c|c|}
\hline \multirow[b]{2}{*}{ Continent } & \multirow[b]{2}{*}{ Registered } & \multicolumn{2}{|c|}{ Leprosy patients } & \multirow{2}{*}{$\begin{array}{c}\text { Treated } \\
\% \text { estimated }\end{array}$} \\
\hline & & Estimated & Total & \\
\hline Africa & I,708,855 & 3,865, ооо & 969,7 I 7 & $24 \cdot 6$ \\
\hline America & I 79,8 I 3 & 36 I ,53 I & 95,723 & $25 \cdot I$ \\
\hline Asia** & 939,729 & $4,169,268$ & 747,827 & I $7 \cdot 9$ \\
\hline Europe & I 6,5 I 9 & $5^{1,944}$ & 9, I 86 & $17 \cdot 7$ \\
\hline Oceania & 9,28 I & 36,265 & 4,235 & I I $\cdot 7$ \\
\hline
\end{tabular}

* WHO figures produced at the $14^{\text {th }}$ Session of the UNICEF/WHO Joint Committee on Health Policy in April I 965 , Geneva, but based on information received so far.

** China (Mainland) not included.

TABLE 3

An Estimate of the Frequency of Disabilities

\begin{tabular}{|c|c|c|c|}
\hline $\begin{array}{l}\text { Total } \mathcal{N o} \text {. } \\
\text { of cases }\end{array}$ & $\begin{array}{l}\text { Percentage } \\
\text { Disabilities }\end{array}$ & Author & Country \\
\hline $10,55^{\circ}$ & $32 \%$ & Doull ( I 954) & Philippines \\
\hline - & $25 \%$ & Diniz ( I 959) & Brazil \\
\hline - & I $6 \cdot 4 \%$ & Convit ( I 959) & Venezuela \\
\hline - & I $6 \%$ & Montestruc ( I 959) & Martinique \\
\hline 一 & $25 \%$ & Kinnear-Brown ( I 959) & Uganda \\
\hline - & I I $3 \%$ & Gay-Prieto ( I 959) & Spain \\
\hline I ,294 & $3 \mathrm{I} \cdot 6 \%$ & $\begin{array}{l}\text { WHO Leprosy Advisory Team } \\
\text { ( I 959) }\end{array}$ & Northern Nigeria \\
\hline 2,487 & I $2 \cdot 8 \%$ & Guinto & Philippines \\
\hline $400,000+$ & $7 \cdot 5 \%$ & Lechat ( r 96o) & Ex-Belgian Congo \\
\hline 4,025 & $25 \%$ & Mallac ( I 96o) & Gambia \\
\hline I,OOO & $29 \cdot 2 \%$ & Chodankar (1962) & Bombay \\
\hline $200,000+$ & $10 \%$ & Mallac (i962) & Burma \\
\hline 4,96 I & $28 \cdot 8 \%$ & Susman ( 1963) & Gambia \\
\hline $16,000+$ & I $5 \%$ & Mallac ( I 963) & Pogiri, India \\
\hline I $8,000+$ & $29 \cdot 7 \%$ & Glyn Griffiths ( I 964) & Zambia \\
\hline $500,000+$ & I $5 \%$ & Mallac ( I 964) & Andhra Pradesh, India \\
\hline
\end{tabular}


TABLE 4

\section{Estimated Disabilities in the World* Disabilities}

\begin{tabular}{|c|c|c|}
\hline Continent & Degrees $\mathrm{I}-5$ & Degrees $2-5 * *$ \\
\hline Africa & I , I O6, о I 5 & 422,297 \\
\hline America & I 69,844 & I O 5,890 \\
\hline Asia (excluding China) & $\mathrm{I}, 683,55^{\circ}$ & I, O I $8,35^{\circ}$ \\
\hline Europe & I 7,187 & $8,0 \mathrm{I} 4$ \\
\hline Oceania & I I, 685 & 5,270 \\
\hline Total & $2,988,28$ I & $\mathrm{I}, 559,82 \mathrm{I}$ \\
\hline
\end{tabular}

* WHO figures produced at the I $4^{\text {th }}$ Session of the UNICEF/WHO Joint Committee on Health Policy in April, 1965, Geneva, but based on information received so far.

** Classification adopted by the WHO Expert Committee on Leprosy, I960.

How long does it take for deformity to appear after the earliest stages of leprosy? How much grace have we in which to apply therapeutic precautions? In short, what is the latent period between the first appearance of leprosy and the onset of deformity, and what is the clinical pattern of the development of deformity in leprosy? These questions seem to the author to be the keys to the mastery of the disease in its most dreaded aspect, i.e. deformity and/or mutilation. It was to answer them that the present study was undertaken.

Two problems are interrelated and have to be studied together. The first is the latent period: how long does it take for leprosy to cause deformity? But this question cannot be answered without a proper study of the different patterns of deformity which the disease does produce: what are these patterns, and how do they emerge?

Three terms are used throughout this study which require definition: disability, deformity and mutilation. It is accepted that these emotive words are not the ideal for an objective study, but there does not appear to be any acceptable alternative. By disability is meant loss of function; it connotes mainly sensory loss (anaesthesia) which is a severe state of affairs particularly in the hand. By deformity, a deviation from the normal shape or size of the part; by mutilation, a partial or total absorption of the part. These last two terms imply motor paralysis and/or direct damage to the tissues by the lepra bacilli, both of which being the chief concern of this study in relation to the extremities.

\section{Review of the Literature}

Over the past 50 years or so, workers in the field of leprosy have studied the local and general manifestations of the disease in minute details, but it seems to the author that they have ignored two cardinal features, namely the latent period of 'germination' of leprosy leading to deformity and the clinical pattern of the latter, particularly the sequence of involvement of the digits.

From time immemorial leprosy has been feared for its contagiousness. Through the centuries the image of the disease has been the image of its late and neglected stages, i.e. deformity and/or mutilation. It is still an image associated with all that is loathsome and unclean. The late James Doull (ig63) put it aptly: 'Although more than 88 years have elapsed since the announcement of the discovery of the leprosy bacillus, an accepted method of in vitro cultivation has not been reported, nor has any one succeeded in producing disseminated leprosy in an experimental animal. These are obviously the great handicaps to progress and it is interesting to speculate on why greater progress has not been made. Some of the reasons are as follows: there are inhibitions resulting from the failures of able scientists in the past. New prospects, especially in the study of ricketsia and viruses, appear to offer quicker returns. There is a public demand for the investigation of the diseases of greater magnitude, such as cancer, heart and mental diseases. There is the significant fact that leprosy is uncommon in most countries that have become leaders in scientific endeavours. Add to these the world-wide shortage of scientific personnel and 
the increase in demand of the physical sciences and we have a formidable list to be overcome before any comprehensive attack can be made on the basic problem of leprosy'.

Today, with the introduction of the sulphones in 1947 , leprosy demands a wider study because it is now curable. With this new intent, attention is being paid to basic research, the various clinical forms of the disease, its bacteriology, its classification, its pathology and immunology. Much has been written on the epidemiology of leprosy, on its reactional phases, on rehabilitation and leprosy control. While all these are of great value, it is the author's opinion that the time scale of this dynamic disease is of equal importance once the cure becomes possible.

Brand ( I 958) made a classic study of the pathology of deformity. According to him most of the terror surrounding the word 'leper' comes from the idea of gross deformity and open sores. Although a great deal of work needs to be done before one can claim to understand the pathology of deformity, Brand suggested as a beginning that it be divided into Primary and Secondary deformity.

The neurological patterns of leprosy in terms of disorders of sensation, nerve involvement, trophic, vascular and ocular changes have been studied by Wayson and Badger (1929), BresaniSilva (1956-7) and Argenta (196I). Andersen ( 1963) elaborated the patterns of anaesthesia and of motor paralysis of neural leprosy. However, these studies have not been concerned with the progression of the disease so much as with different syndromes atdifferent and unrelated stages.

Whereas it was held that neural signs in leprosy are due to an inevitable and irreversible degeneration of the affected nerves, Chatterjee ( 955 and I 964) proved the important point that this is not so. Neural signs are due more to vascular than to neural changes and that these are not irreversible. Encouraging results were obtained in both the prevention and correction of polyneuritic signs, as well as in the eradication of their residual ones.

When it comes to the aetiology of bone changes Murdock and Hutter ( 1932 ) were of opinion that neural or neuro-vascular factors were the main causes of bone changes in leprosy. More recently, Oberdöffer and Collier ( 1940 ) have pointed out that disturbances of nutrition which cause atrophy of both the cortex and cancellous bone can also follow the paralysis of muscles inserted into them, secondary to the neurological lesions. Cuervo et al (1944) agreed that the majority of bone lesions are neurotrophic but have shown that in the lepromatous variety they are due to the direct action of M.leprae on the osseous tissue. Again, while Faget and Mayoral (1944) agreed that bone changes are neurotrophic lesions to which trauma is contributory, they found that it is long standing leprous neuritis and disturbance of the nutritional function of the affected nerve which is the main cause of bone absorption. Others have drawn attention to the part played by disturbances of circulation, anaesthesia, pressure and changes in acid-base equilibrium brought about by the metabolism of M.leprae (Cooney and Crosby i 944, Barondes 1946, Esquerra-Gomez and Acosta 1948, and Barnetson I95I). Da Veiga ( 1947) regarded osteoporosis as being due primarily to vascular disturbances; Wozonig ( 1956 ) that non-specific trophic disturbances secondary to neural involvement are the causes of bone changes in leprosy.

Thus recent studies have largely refuted the classical concept that bone destruction in leprosy was a simple process of anaesthesia and trauma and that those neural or neuro-vascular factors were the main causes of bone changes. Patterson ( 1958) puts forward a soft tissue chronic nonspecific infection as the main cause of bone absorption and Brand (1958) that one of its main causes is the misuse of the finger tips. Early diagnosis should enable the reversible process of trabecular absorption and decalcification to bc at worst halted, and at best reversed. None of these observers, so far, have indicated how long is the latent period during which such treatment might be applicable.

Further evidence which emphasizes the importance of early diagnosis in leprosy has come from the study of the role of ischaemia in the pathogenesis of bone changes. Vascular lesions of the type specific to leprosy have been found in more than half of the cases studied by Fite (I 94I): the organisms were present in endothelial cells of terminal vascular loops, sometimes forming a mass projecting into the lumen. Clearly, at this stage, the pathological process should be: reversible if the diagnosis could have been made.

\section{Leprosy Review}


Two approaches to using more specialised methods for establishing the early diagnosis at this potentially reversible stage have been exploited, on the one hand by study of the alteration in peripheral nerve function by means of measurements of chronaxie*; on the other hand, the detection of early vascular changes by oscillometry, skin temperature studies, and arteriography.

In I 942, Freitas and Virgilio utilised electrical stimulation as a means of precise localization of the peripheral nerve lesion in leprosy. This technique was developed by Dubois (I95I) and Raedermecker (1952) into a useful means of establishing early diagnosis of minimal nerve lesions: they found alterations in the chronaxie before there were any other clinical signs. Lechat ( I 960) extended this work further. He found that although there was no relationship between the incidence of osseous changes and the clinically paralysed groups of muscles, there were definite alterations in chronaxie, indicating latent motor weakness in these cases with or without anaesthesia. However, Lechat did find evidence of distal absorption of digits and disorganization of joints in cases without even these alterations in chronaxie. This work would suggest that chronaxiemetry may be useful, but not a completely reliable early screening method in the diagnosis of the onset of deformity.

Barnetson (1950) made a detailed study with oscillometry on neural cases. He showed that local blood vessels had not lost their dilatability but vaso-motor control was defective, though he thought that the neurotrophic changes depended on more factors than loss of vasomotor control. Gokhale (r 959) studied the temperature changes in the feet after blocking the autonomic system, and found that vaso-motor control was defective in the ulcerated feet of the leprosy patients. Bang and Diep ( 1958) showed by arteriography that there is an ample blood supply even in advanced cases. Patterson ( I 955) showed narrowing of the digital arteries in extreme deformity. But neither this author nor the subsequent studies of Chardome and Lechat (I957), Lechat (I960) and Basu (I962) have thrown light on the question whether these arterial changes are primary, or secondary to the tissue destruction. On the other hand, measurements of skin temperature (Barnetson
I 950, Katsumi i 955, Lechat i 96o, Montestruc and Hydronimus I 96 I) suggest that there is a distinct lesion, amounting to loss of vasodilator control in response to heat, in these patients.

On the plea that arterial changes in the form of an endarteritis causes slowing of the peripheral circulation and prolonged venous return in the affected parts, Lechat (I960) puts forward the hypothesis that absorption of the bone develops when the nervous mechanism controlling vasoregulation of the skin is damaged, the terminal vascular system is no longer able to adapt the flow of the peripheral blood to the demands that follow multiple and constant neuro-traumatisms at the level of the tips.

So far, neurotrophic and vascular factors have been considered in the aetiology of bone changes, but metabolic factors have been studied since the pioneer work of Honeij ( I 9 I 7) who tried to find out whether there was an abnormality of calcium metabolism in leprosy and whether changes in serum calcium concentration was correlated with the degree of mutilation. Honeij reached no definite conclusions. Later groups of workers have reported a hypercalcaemia in cases improving on treatment, with a hypocalcaemia during reactional phases (Badenoch and Byron I 932, Esquerra-Gomez i 948).

Not all workers have agreed with these findings. For example, Wooley (I93 I) found a hypocalcaemia particularly among the several neural cases; similar findings were obtained by Wooley and Ross (1933), Nishikawa (1932), Ross (1955) and Dhople and Magar (1962).

Still others have found no significant alterations in the serum calcium, or else a complete want of correlation between the stages of the disease and the calcium level, namely Venkatasubramanian (194I). Yet, Lindui and Ross ( I 957) found no relationship between blood levels of calcium and the evolution of deformity, the studies of Lechat ( 1960 ) and those of Languillon and Boissan ( 1960 ) confirming these results.

No correlation can be found between the phosphorus levels and the state of the disease (Wooley and Ross i 932, Ross i 955, Lindui and

* By chronaxie or chronaxiemetry is meant the shortest duration of a current necessary for excitation when its strength is twice the rheobase. Readings vary from muscle - I/ IO to I/4 of sigma or thousandth of a second-In the presence of neuritis, nerve or muscle involvement, readings increase $5^{0}$ to roo times the normal value or more. 
Ross i 957, Lechat i 96o, Languillon et al. i 96o and Dhople and Magar ig62). It seems then that calcium and phosphorus estimations are of no practical value in detecting the subsequent progress of the disease.

Similar disappointment has followed the use of serum alkaline phosphatases. Venkatasubramanian (I 94I) was the first investigator; he thought that the mutilations, more marked in the 'pure' neural form, could be reflected in an increase in alkaline phosphatases, but Ross (1955) found it within normal limits in both the mutilated and the non-mutilated patients. Four years later, Imaeda ( $1959-60$ ) found that it was raised in the leprosy patients and suggested that phosphatase was related to nerve destruction. Lechat ( 1960) also found a difference in the phosphatase levels between the mutilated patients and the healthy individuals of his group, but found no correlation with the state of the bone lesions. Dhople and Magar ( 1962) found that the average values were within normal limits in the early stages of the disease, but were increased in severe tuberculoid cases. As an index to early diagnosis, the alkaline phosphatases prove useless.

Wooley and Ross ( I 932) were among the first to investigate the role of blood proteins in leprosy. They concluded that in the disease the albuminglobulin ratio was lower and the globulin fraction increased against controls. These findings were confirmed by Muelling et al. ( 1960 ), Mille and Papa (I96I) and 'Torsuceva (I962). Lechat ( 1960$)$ made a serial blood protein analysis in mutilated and non-mutilated patients, and in normal controls. He found that the beta-globulin fraction was lower in the mutilated patients than in the non-mutilated, a difference which was also influenced by age and the duration of the disease. Gamma-globulins were significantly increased in both groups of patients with leprosy as compared with the healthy group, being higher in the mutilated cases.

Radiological investigations have been used in the attempt to chart the progress of leprosy, and to assist in the classification of its various manifestations. Studies (reviewed above) have been made into the aetiology of bone changes. Classification of the end stages of the disease based on radiological appearances is now securely based, thanks to the publications of Kadrenka and
Merdje (1938), Erickson and Mayoral (1950), Casacci (1950), Barnetson (1950), Cherlinzoni and Piratsu (1952), Mut Mut (r 955), Chardome and Lechat (1955), Patterson (1956), K'ung Ch'ing-teh el al. (1957), Negre and Fontan (1957), Zamudio (1960), Languillon and Carayon ( I96r ) and Lechat ( 1962).

It is clear, however, that sequential studies in which the clinical picture is correlated with the radiological ones, and in which the progress of the disease in its different patterns can be followed in time, are still wanting. In recent years the radiological changes in leprosy in response to treatment have been studied by Erickson and Johansen (1 948), Basset and Schneider (1950), Lechat and Chardome (I 957), and Languillon and Boissan (1960). From these it is also clear that treatment may, if too late, fail to halt the progress of deformity once it has begun. Although reiterating the importance of early diagnosis, these radiological findings have not been concerned with the way different patterns, having different rates of progression, can emerge early in the course of the illness.

Mathur and Saxena ( I 965) observed that some cases of deformity, particularly the early ones, treated with intraneural Priscol give satisfactory and promising results on the whole, both in correction and prevention.

Lennox ( 1964 ) forwarded a usef ul classification of leprosy foot deformities, stressing the close relationship of deformity to trophic ulceration.

As a by-product of their general findings in Nigeria, Cameroon, Thailand, Burma and the Philippines, the WHO Leprosy Advisory Team ( 1965 ) found out that the longer the period prior to treatment, the greater the proportion of disabilities.

From all the above investigations, no single biochemical or radiological test emerges as an accurate or reliable method which will replace clinical examination in early diagnosis and in the recognition of early deformity, and the role of chronaxiemetry is seen to be supplementary to clinical investigation. Throughout all these studies, however, the theme emerges again and again that many of the early lesions, both of peripheral nerves and small blood vessels are reversible, and that if reversed, bone destructionwith deformity and mutilation could be prevented.

For this reason, it seems all the more important

\section{Leprosy Review}


for the physician to know how urgent the treatnent is or how long cloes leprosy take to reach a stage when treatment becomes salvage, not cure.

None of the studies bricfly reviewed herc have dealt specifically with the onset of deformity of the extremities and with the sequence of events regarding the affected digits, yet the information is fundamental to any large scale attack upon leprosy. Planning and execution of public health measures dealing with the disease must in our generation be directed not only against the curable stages but also against its most dreaded and seemingly inexorable aspect; deformity. Before such plans can be made, the planner must be provided with his basic data.

Part and parcel of the study of the evolution of the clinical picture of leprosy must be data on the onset of deformity and the sequence of events concerning the affected digits. As this review of the literature has shown, there have been a great many studies on the disease as a static entity, many descriptions of the end stages of the disease process. The gap in our knowledge is the timing, the dynamic study of leprosy. To fill this gap is the object of the present study.

\section{Plan and Description of the Investigations}

There is a delay between the first signs of leprosy and the manifestation of deformity: how long is this clelay and how long this period of 'gcrmination' of the cliscase leading to cleformity?

From the foregoing revicw of the literature, it appears that one out of lour or five patients with leprosy will develop some sort of deformity or other: how soon in the case of a male patient still in his teens? How soon if it is a case of Tuberculoid leprosy? How long after the start of the disease when concerning a female in her early thirties, and a lepromatous type? How long af ter the start of the disease when it is a male in his late thirties of the indeterminate or borderline group? In other words, how long does deformity take to develop as between the clinical forms, the sex and in the different age groups? How long also from one extremity to the corresponding and/or the opposite one(s)?

From the start it was obvious that the problem could only be studied in patients who would be reliable witnesses and who could answer a number of questions. Few patients met these conditions in the parts of Africa where the author started his career, and also in India. In Burma, however, there is a better school attendance in urban and rural areas and more patients were available who could understand and co-operate on this study. It was then in Burma that the necessary informations were obtained: 700 patients with deformity were examined in detail.

TABLE 5

Choice of Out-patients and Their Percentage Examined

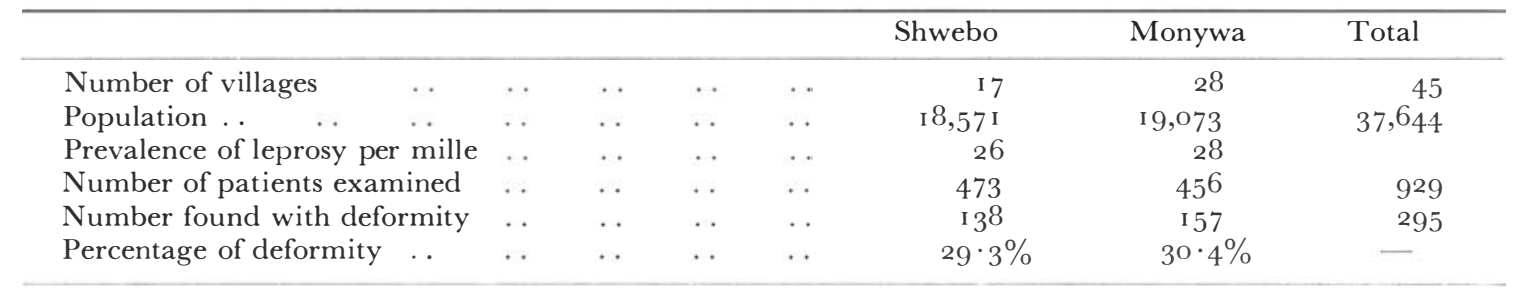

TAB LE 6

Choice of In-patients and Their Percentage Examined

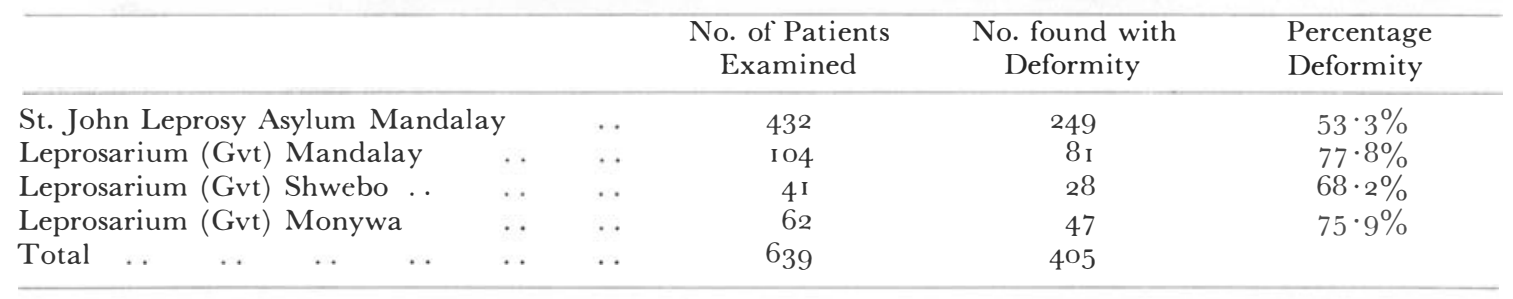


The plan of investigations was as follows: visits to enough villages where the disease was known to be prevalent, with the purpose of examining registered cases at the clinics and in their homes as well as in many leprosaria. A detailed questionnaire and a recording of findings was used for every patient found with deformity of the extremity(ies). Analyses of these results built up a composite picture of its clinical patterns.

From the above two tables, we have the following :
Total $\mathcal{N}$ o. of Out-patients examined

Total $\mathcal{N}$ o of In-patients examined

Grand total of patients examined

Total No. found with deformity

IV Results of the Investigations

A. The Onset of Deformity

- Between Clinical Forms

- Per Sex

- Per Age Group

TABLE 7

The Onset of Deformity Between Clinical Forms

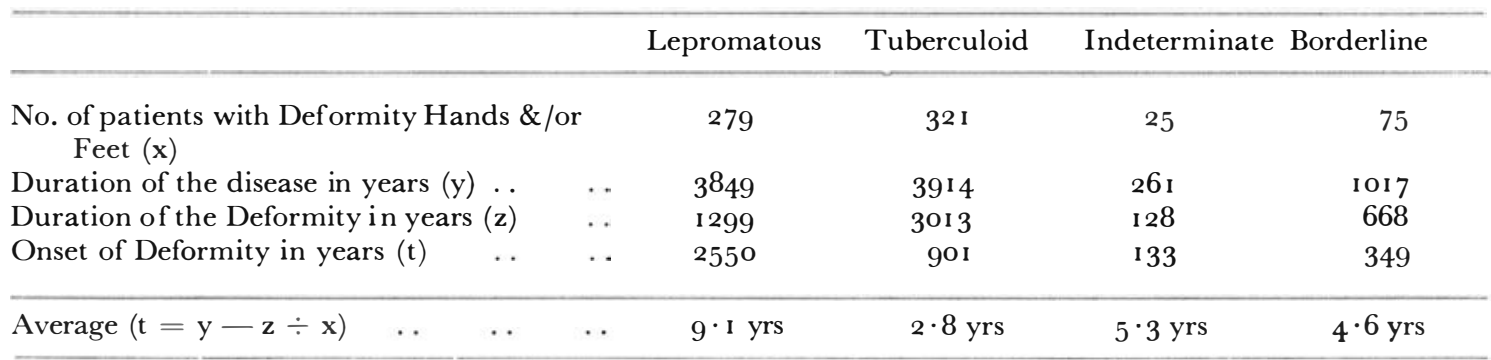

OBSERVATIONS

Deformity occurred an average of 2 years and 9 months after the start of the disease in the tuberculoid cases; an average of $4 \frac{1}{2}$ years in the borderline; an average of 5 years and 3 months in the inderterminate and an average of 9 years and $\mathrm{I}$ month in the lepromatous.

The time of onset of deformity was thus about 3 times as long in the lepromatous than in the tuberculoid; twice as long in the lepromatous than in the borderline; twice as long in the indeterminate as in the tuberculoid.

TABLE 8

The Onset of Deformity per Sex

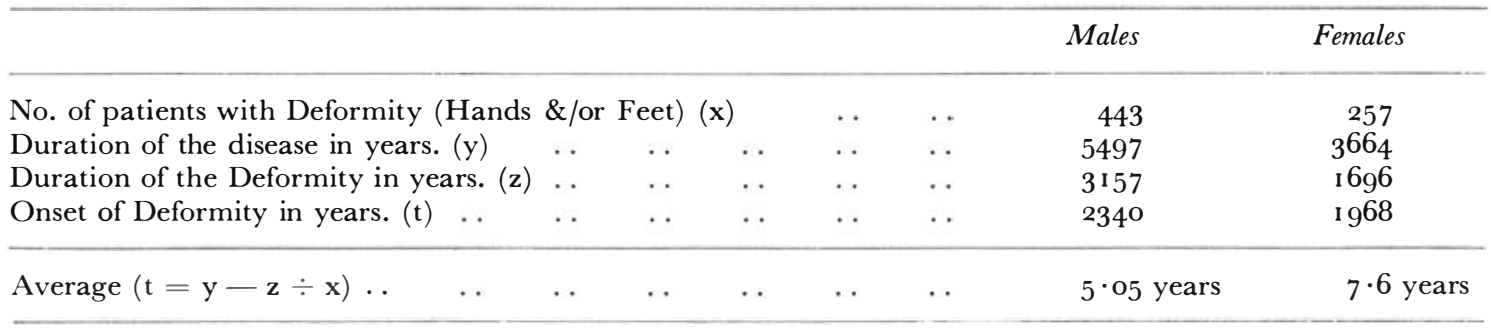

OBSERVATIONS

Men were earlier affected, an average of 5 years after the start of the disease as opposed to an average of $7 \frac{1}{2}$ years in the case of women. 
TABLE 9

The Onset of Deformity per Age Group

\begin{tabular}{|c|c|c|c|c|c|c|c|}
\hline & $\mathrm{o}-5$ & $6-10$ & I I -20 & $2 \mathrm{I}-30$ & $3 \mathrm{I}-40$ & $4^{1-50}$ & $5 \mathrm{I}+$ \\
\hline No. of patients with Deformity in years $(\mathbf{x})$ & - & - & $9^{I}$ & 277 & I95 & 98 & 39 \\
\hline Duration of the disease in years. $(y)$ & - & - & $59^{1}$ & 3210 & 3122 & I $54^{\circ}$ & 873 \\
\hline Duration of the Deformity in years. $(z)$ & - & - & 323 & 1677 & I 770 & 8 I5 & 520 \\
\hline Onset of Deformity in years. $(t)$ & - & - & 268 & I 352 & $135^{2}$ & 725 & 353 \\
\hline Average $(t=y-z \div x)$ & - & - & $2 \cdot 7 \mathrm{yrs}$ & 5 yrs & $6 \cdot 8 \mathrm{yrs}$ & $7 \cdot 3 \mathrm{yrs}$ & $9 \cdot 05 \mathrm{yrs}$ \\
\hline
\end{tabular}

OBSERVATIONS

In this study, no deformity was observed in the $0-5$ and the $6-10$ age groups.

Deformity appeared an average of 2 years and 8 months in the $11-20$ age group ( $13 \%$ of the total); an average of $5 \frac{1}{2}$ years in the $21-30$ age group $(39.5 \%)$; an average of 6 years and 9 months in the $31-40$ age group $(27 \cdot 8 \%)$; an average of 7 years and 4 months in the $41-50$ age group $(14 \%)$; and an average of 9 years in the 5 I years old onwards $(5 \cdot 5 \%)$.

Thus the younger the age group on the whole, the earlier seemed the onset of deformity.

B. The Clinical Pattern of Deformity

(i) Deformity of the Hand:

Comparative Frequency of Deformity of the Hand between Clinical Forms

Comparative Frequency of Deformity of the Hand per Sex

Comparative Frequency of Deformity of the Hand per Age Group

Pattern of Deformity of the Hand

General Mode of Involvement of the Affected Fingers

Average Interval between Affected Fingers of both Hands.

TABLE IO

Comparative Frequency of Deformity of the Hand between Clinical Forms

\begin{tabular}{|c|c|c|c|c|}
\hline & Lepromatous & Tuberculoid & Indeterminate & Borderline \\
\hline Total No. of examined patients $\ldots$ & 627 & $63^{2}$ & I 86 & I 23 \\
\hline$\%$ incidence of the type of the disease .. & $39 \cdot 4 \%$ & $40 \%$ & II $\cdot 2 \%$ & $7 \cdot 7 \%$ \\
\hline Total No. with deformity of the hand(s) & 266 & 308 & 25 & 75 \\
\hline$\%$ incidence of deformity of the hand $(\mathrm{s})$ & $4^{2} \cdot 2 \%$ & $48 \cdot 5 \%$ & $13 \cdot 8 \%$ & $60 \cdot 9 \%$ \\
\hline
\end{tabular}

OBSERVATIONS

Deformity of the hand(s) was proportionately more frequent among the Borderline cases $(60 \cdot 9 \%$ representing $7 \cdot 7 \%$ of the total).

Next among the Tuberculoid, $48 \cdot 5 \%(40 \cdot 4 \%$ of the total).

Then among the Lepromatous, $42 \cdot 2 \%(39 \cdot 4 \%$ of the total $)$ and finally among the Indeterminate, $7 \cdot 7 \%$ (II $\cdot 2 \%$ of the total).

TABLE I I

\section{Comparative Frequency of Deformity of the Hand per Sex}

\begin{tabular}{|c|c|c|c|c|c|}
\hline & $\begin{array}{l}\text { Total cases } \\
\text { examined }\end{array}$ & Grouping & Sex Incidence & $\begin{array}{l}\text { No. Found with } \\
\text { Deformity }\end{array}$ & $\begin{array}{l}\text { \% Incidence of } \\
\text { Deformity }\end{array}$ \\
\hline Males & I 568 & 953 & $60 \cdot 8 \%$ & $4^{10}$ & $43 \cdot 02 \%$ \\
\hline Females & & 615 & $39 \cdot 2 \%$ & 264 & $42 \cdot 7 \%$ \\
\hline
\end{tabular}


OBSER V A TIONS

Among the total of 953 males examined, 4 Io $(43 \%)$ showed deformity of the hand(s).

Among the total of 6 I 5 females examined, $264(42 \cdot 7 \%)$.

Men were thus hardly more affected than women with regards to the deformity of the hand(s).

TABLE I 2

Comparative Frequency of Deformity of the Hand per Age Group

\begin{tabular}{|c|c|c|c|c|c|c|c|}
\hline & $0-5$ & $6-10-$ & I I -20 & $2 \mathrm{I}-3 \mathrm{O}$ & $3^{1-40}$ & $4^{I-50}$ & $5 \mathrm{I}+$ \\
\hline No. of patients with Deformity & - & - & $9^{\mathrm{I}}$ & 277 & I 95 & 98 & 39 \\
\hline No. of patients with Deformity of the Hand(s) & - & - & 87 & 267 & I 84 & 97 & 39 \\
\hline$\%$ Deformity of the Hand(s) & - & - & $95 \cdot 6 \%$ & $96 \cdot 3 \%$ & $94 \cdot 3 \%$ & $98 \cdot 9 \%$ & $\mathrm{I} 00 \%$ \\
\hline
\end{tabular}

OBSERVATIONS

Deformity of the hand appeared in the $\mathrm{I} I-20$ age group.

It was more common in the $2 \mathrm{I}-30$ age group and thereaf ter declined steadily with age.

Irrespective of the age group concerned, the percentage deformity of the hand(s) was proportionately very high.

T A L.E I 3

Pattern of the Deformity of the Hand

\begin{tabular}{|c|c|c|c|c|c|c|c|c|c|}
\hline & & & & & Right & Left & Bilateral & Total & $\%$ Incidence \\
\hline A2.* Mobile claw-hand(s) & . & . . & .. & . & 77 & 68 & $9^{\mathrm{I}}$ & 236 & $29 \cdot 8 \%$ \\
\hline A3. Contracture $\ldots$ & . & . & . & . & 69 & 95 & 164 & 328 & $41 \cdot 4 \%$ \\
\hline A4. Partial absorption & .. & .. & . & .. & 44 & 25 & I 22 & I 9 I & $24 \cdot 1 \%$ \\
\hline A5. Gross absorption .. & .. & .. & .. & .. & 7 & 5 & 24 & 36 & $4 \cdot 5 \%$ \\
\hline
\end{tabular}

* As per the WHO Classification (1960).

OBSERVATIONS

The commonest type of deformity of the hand was contracture $(40 \cdot 4 \%)$.

Next, mobile claw-hand $(29 \cdot 8 \%)$.

Then partial absorption of the fingers with useful thumb remaining $(24 \cdot 1 \%)$ and finally, gross absorption of the fingers $(4 \cdot 5 \%)$.

Bilateral involvement was appreciably more common than unilateral involvement:

\begin{tabular}{|c|c|}
\hline Bilateral Involvement (Mixed Types) & $5^{18}(74 \cdot 3 \%)$ \\
\hline Unilateral $\quad, \quad, \quad$, & I $56(22 \cdot$ I \% $)$ \\
\hline No Involvement of the $\operatorname{Hand}(\mathrm{s})$ & $26(3 \cdot 6 \%)$ \\
\hline Total & 700 \\
\hline
\end{tabular}

8o Leprosy Review 
TABLE I 4

General Mode of Involvement of the Affected Fingers

\begin{tabular}{|c|c|c|c|c|c|}
\hline \multirow[b]{2}{*}{ Fingers } & \multicolumn{2}{|c|}{ Unilateral Involvement } & \multirow{2}{*}{$\begin{array}{c}\text { Bilateral } \\
\text { Involvement }\end{array}$} & \multirow[b]{2}{*}{ Total } & \multirow[b]{2}{*}{$\%$ Incidence } \\
\hline & Solely & In the first place & & & \\
\hline Ist & 8 & 6 & 36 & 50 & $7 \cdot 4 \%$ \\
\hline 2nd & Io & 7 & 69 & 86 & $\mathrm{I} 2 \cdot 8 \%$ \\
\hline $3 \mathrm{rd}$ & - & 6 & 45 & $5 \mathrm{I}$ & $7 \cdot 6 \%$ \\
\hline $4^{\text {th }}$ & I & 6 & 22 & 29 & $4 \cdot 3 \%$ \\
\hline $5^{\text {th }}$ & 38 & 23 & 304 & 365 & $54 \cdot 4 \%$ \\
\hline $4^{\text {th }}+5^{\text {th }}$ & - & I 8 & 5 & 23 & $3 \cdot 4 \%$ \\
\hline Simultaneous involvement & II & - & 34 & 45 & $6 \cdot 6 \%$ \\
\hline Mixed involvement & 25 & - & - & 25 & $3 \cdot 7 \%$ \\
\hline
\end{tabular}

OBSERVATIONS

The $5^{\text {th }}$ or little finger was by far the most commonly involved $(54 \cdot 5 \%)$.

Next the 2nd or index finger (12.8\%); then the ist finger or thumb $(7 \cdot 4 \%)$ and the 3 rd finger or middle one.

Finally the simultaneous involvement of fingers $(6 \cdot 6 \%)$; the $4^{\text {th }}$ or ring finger $(4 \cdot 3 \%)$; the combined $4^{\text {th }}$ and $5^{\text {th }}$ (Pure Ulnar Palsy), $3 \cdot 4 \%$, and the mixed involvement of fingers $(3 \cdot 7 \%)$.

TABLE I 5

Average Interval between Affected Fingers of both hands

\begin{tabular}{lll} 
& Total & Average Interval \\
\hline From Right to Left & 207 & $2 \cdot 2$ years \\
From Left to Right & I 66 & $2 \cdot$ I years \\
\hline
\end{tabular}

O B S E R V A T I O N S

When both hands were effected in turn, it was found that the involvement from right to left was more common than the involvement from left to right.

Practically no difference was detected between their respective average interval, the latter being just over 2 years for both.

B. The Clinical Pattern of Deformily

(ii) Deformity of the Foot:

Comparative Frequency of Deformity of the Foot between Cilinical Forms

Comparative Frequency of Deformity of the Foot per Sex

Comparative Frequency of Deformity of the Foot per Age Group

Pattern of Deformity of the Foot:

General Mode of Involvement of the affected Toes

Average Interval between affected toes in both Feet

TABLE I 6

Comparative Frequency of Deformity of the Foot between Clinical Forms

\begin{tabular}{|c|c|c|c|c|}
\hline & Lepromatous & Tuberculoid & Indeterminate & Borderline \\
\hline Total No. of examined patients & 627 & $63^{2}$ & I 86 & I 23 \\
\hline$\%$ incidence of the type of the disease & $39 \cdot 4 \%$ & $40 \cdot 03 \%$ & II $\cdot 2 \%$ & $7 \cdot 7 \%$ \\
\hline I'otal No. with deformity of the foot & I 72 & 215 & I9 & $5^{2}$ \\
\hline$\%$ incidence of deformity of the foot & $27 \cdot 4 \%$ & $34 \cdot 01 \%$ & $10 \cdot 2 \%$ & $42 \cdot 2 \%$ \\
\hline
\end{tabular}

Onset and Pattern of Deformity $8 \mathrm{I}$ 
O B S E R V A T I O N S

Deformity of the foot was proportionately more frequent among the Borderline cases $(42 \cdot 2 \%$ representing $7 \cdot 7 \%$ of the total).

Next among the Tuberculoid group, $34 \%(40 \%$ of the total).

Then among the Lepromatous, $27 \cdot 4 \%(39 \cdot 4 \%$ of the total), and finally the Indeterminate, $10 \cdot 2 \%(\mathrm{I} \cdot 2 \%$ of the total).

TABLE I 7

Comparative Frequency of Deformity of the Foot per Sex

\begin{tabular}{|c|c|c|c|c|c|}
\hline & $\begin{array}{l}\text { Total cases } \\
\text { examined }\end{array}$ & Grouping & $\begin{array}{c}\text { Sex } \\
\text { incidence }\end{array}$ & $\begin{array}{l}\text { No. found with } \\
\text { deformity }\end{array}$ & $\begin{array}{l}\text { \% Incidence } \\
\text { of deformity }\end{array}$ \\
\hline Males & \multirow{2}{*}{ I 568} & 953 & $60 \cdot 8 \%$ & 28 I & $30 \cdot 1 \%$ \\
\hline Females & & 615 & $39 \cdot 2 \%$ & I 77 & $25 \cdot 5 \%$ \\
\hline
\end{tabular}

O B S E R V A T I O N S

Among the total of 953 males examined, $28 \mathrm{I}(30 \cdot \mathrm{I} \%)$ showed deformity of the foot.

Among the total of $6{ }_{15}$ females examined, $177(27 \cdot 5 \%)$.

Men were thus slightly more affected than women.

TABLE I 8

Comparative Frequency of Deformity of the Foot per Age Group

\begin{tabular}{|c|c|c|c|c|c|c|c|}
\hline & $0-5$ & $6-10$ & I $1-20$ & $21-30$ & $3^{1-40}$ & $4^{I-50}$ & $50+$ \\
\hline No. of patients with deformity & - & - & $9^{1}$ & 277 & 195 & $9^{8}$ & 39 \\
\hline $\begin{array}{l}\text { No. of patients with deformity of the foot } \\
\% \text { deformity of the foot }\end{array}$ & - & - & $\begin{array}{c}3 \mathrm{I} \\
35 \cdot 06 \%\end{array}$ & $\begin{array}{r}199 \\
68 \cdot 5 \%\end{array}$ & $\begin{array}{r}136 \\
69 \cdot 7^{\circ}\end{array}$ & $\begin{array}{c}59 \\
60 \cdot 2 \%\end{array}$ & $\begin{array}{c}33 \\
84 \cdot 8 \%\end{array}$ \\
\hline
\end{tabular}

O B S E R V A T I O N S

Deformity of the foot appeared in the $\mathrm{I} I-20$ age group.

It was more common in the $2 \mathrm{I}-30$ age group and thereafter steadily declined with age.

Irrespective of the age group concerned, the percentage deformity of the foot was, like in the hand, proportionately quite high.

TABLE I 9

Pattern of Deformity of the Foot

\begin{tabular}{|c|c|c|c|c|c|c|c|c|c|}
\hline & & & & & Right & Left & Bilateral & Total & $\%$ Incidence \\
\hline B2. & Perforating ulcers & .. & . & . & $5^{8}$ & $5^{8}$ & 326 & $44^{2}$ & $42 \cdot 6 \%$ \\
\hline B3. & Claw-toes \&/or foot-drop & & . & . & 83 & I 16 & 203 & 402 & $38 \cdot 7 \%$ \\
\hline B4. & Partial absorption & . & .. & . & 49 & 62 & 60 & I 7 I & $16 \cdot 5 \%$ \\
\hline B5. & Gross absorption .. & .. & $\ldots$ & $\ldots$ & 9 & 6 & 7 & 22 & $2 \cdot 1 \%$ \\
\hline
\end{tabular}

OBSERVATIONS

The commonest type of deformity of the foot was perforating ulcers $(42 \cdot 6 \%)$.

Next, claw-toes (including foot-drop), $38 \cdot 7 \%$.

Then partial absorption of the foot $(16 \cdot 5 \%)$ and gross absorption $) 2 \cdot 1 \%$ ).

$\begin{array}{ll}\text { Bilateral Involvement (Mixed Types) } & =328(46 \cdot 8 \%) \\ \text { Unilateral }, " ~ & =130(17 \cdot 1 \%) \\ \text { No Involvement of the Foot } & =242(34 \cdot 5 \%) \\ \text { Total } & =700\end{array}$

82 Leprosy Review 
TABLE 20

General Mode of Involvement of the Affected Toes

\begin{tabular}{|c|c|c|c|c|c|}
\hline \multirow[b]{2}{*}{ TOES } & \multicolumn{2}{|c|}{ Unilateral Involvement } & \multirow{2}{*}{$\begin{array}{l}\text { Bilateral } \\
\text { Involvement }\end{array}$} & \multirow[t]{2}{*}{ Total } & \multirow[t]{2}{*}{$\%$ Incidenc } \\
\hline & Solely & $\begin{array}{l}\text { In the first } \\
\text { place }\end{array}$ & & & \\
\hline Ist & I3 & $3^{6}$ & 152 & 201 & $47.8 \%$ \\
\hline 2nd & 2 & 12 & 50 & 64 & $15.3 \%$ \\
\hline $3^{\text {rd }}$ & 1 & 6 & 37 & 44 & $10.4 \%$ \\
\hline $4^{\text {th }}$ & 1 & 5 & 32 & $3^{8}$ & $9.5 \%$ \\
\hline $5^{\text {th }}$ & 2 & 8 & 40 & $5^{\circ}$ & II. $9 \%$ \\
\hline $\begin{array}{l}\text { Simultaneous } \\
\text { Involvement }\end{array}$ & \multicolumn{2}{|c|}{3} & 6 & 9 & $2 \%$ \\
\hline Mixed Involvement & \multicolumn{2}{|c|}{14} & 一 & 14 & $3 \cdot 3 \%$ \\
\hline
\end{tabular}

\section{OBSERVATIONS}

The Ist or big toe was by far the most commonly involved $(47.8 \%)$

Next the 2 nd toe $(15.2 \%)$; then the $5^{\text {th }}(11.9 \%)$; the 3 rd $(10.4 \%)$; the $4^{\text {th }}(9.5 \%)$

Finally, the mixed involvement of toes $(3 \cdot 3 \%)$ and their simultaneous involvement $(2 \%)$

B. The Clinical Pattern of Deformity

(iii) The Combined Deformity of Hand and Foot

Of the 700 cases with deformity, $43^{2}(61.7 \%)$ had combined deformity of hand and foot, an unusually high incidence which necessitated further investigation

As would be expected, their comparative frequency between clinical forms, per sex and per age group was identical as in the case of the hand and foot alone

The general pattern of the combined deformity and the average interval between hand and foot and foot and hand will only be considered here.

TABLE 2 I

General Pattern of the Combined Deformity

\begin{tabular}{|c|c|c|c|c|}
\hline \multirow[t]{2}{*}{ Involvement } & \multicolumn{2}{|c|}{ Frequency } & \multirow[t]{2}{*}{ Total } & \multirow[t]{2}{*}{$\%$ Incidence } \\
\hline & Males & Females & & \\
\hline Right hand + right foot & 9 & 4 & I 3 & $3 \%$ \\
\hline Right hand + left foot & 4 & 2 & 6 & $1.3 \%$ \\
\hline Right hand + both feet & Io & 3 & 13 & $3 \%$ \\
\hline Left hand + left foot & 4 & 2 & 6 & $1.3 \%$ \\
\hline Left hand + right foot & 5 & 4 & 9 & $2.8 \%$ \\
\hline Left hand + both feet & 4 & 9 & 13 & $3 \%$ \\
\hline Both hands + right foot & $3^{2}$ & I6 & 48 & I I. I \% \\
\hline Both hands + left foot & $4^{2}$ & 20 & 62 & $14 \cdot 3 \%$ \\
\hline Both hands + both feet & 157 & 105 & 262 & $60.2 \%$ \\
\hline
\end{tabular}

\section{OBSERVATIONS}

The commonest pattern of involvement of clinical importance was both hands and both feet $(60.2 \%)$

Next both hands and the left foot $(14.3 \%)$ and both hands and the right foot ( 1 I . I \% )

Males and females were almost equally affected 
TA B LE 22

Average Interval between Hands and Feet and Feet and Hands

\begin{tabular}{lcc}
\hline & Frequency & Time Interval \\
\hline Hands followed by feet & 239 & $3 \cdot 3$ years \\
Feet followed by hands & 193 & $3 \cdot$ I years \\
\hline
\end{tabular}

O B S E R V A T I O N S

In this series of combined deformity, the average interval between hands and feet was 3 years and 4 months; between feet and hands 3 years and i month.

The difference between these various average intervals was, therefore, not statistically significant.

\section{DISCUSSION}

Leprosy is still a curse rather than a disease amidst a complex emotional background intertwined with prejudice, ignorance and fear. There are an estimated 20 million leprosy sufferers throughout the world and some 3 to 5 million among them are the victims of disabilities which are responsible for the physical, mental and social crippling with which the disease is associated.

This study arose from the need of answering 2 cardinal questions which the literature has ignored over the past 50 years: $(i)$ the onset of deformity of the extremities in leprosy and (ii) the pattern of the deformity within the context of clinical observations. As a result, an analysis of 700 cases of deformity of the extremities was carried out among a selected group of patients.

As Andersen (1963) rightly pointed out, deformities in leprosy have a triple origin, namely motor paralysis, sensory loss and direct damage to the tissues by the leprosy bacillus, and any one clinical deformity may have two or more primary factors interacting together in their secondary manifestations. Deformity from the point of view of motor paralysis and/or direct damage to the tissues by M.leprae is our chief concern here, though it must be stated that sensory loss (anaesthesia) is per se quite a severe disability particularly in the hand. In fact, Brand (1964) emphasized that in the United Kingdom, and also in America, a person with total loss of sensation in the hand and without any other disabilities is graded for insurance purposes as being $100 \%$ disabled for that particular hand.

8.1 Leprosy Review
Onset of Deformity:

In this study, deformity appeared 2 years and 9 months after the start of leprosy among the Tuberculoid cases; an average of $4 \frac{1}{2}$ years among the Borderline; an average of 5 years and 3 months among the Indeterminate and an average of 9 years among the Lepromatous. This means that, although deformity is preventable, although one is aware that measures taken in time would logically ward it off, yet one knows now that one has about 3 years of grace in respect of the Tuberculoid cases (excluding, of course, the polyneuritic or 'pure' neural form); an average of $4 \frac{1}{2}$ years with regard to the Borderline; over 5 years as far as the Indeterminate cases are concerned and 9 years or more when dealing with the Lepromatous patient. These relative years of grace do, in fact, invite us more than ever to be on the look-out for the early signs of deformity. This is of paramount importance, particularly in a national leprosy control programme, since the deformity rate will go on increasing if proper coverage by means of early diagnosis and treatment does not take these years of grace also into account. If leprosy control is to be ultimately achieved, measures ignoring the relative years of grace in respect of each type of the disease age and sex, must be studied, to save further loss in manpower, and more distress to millions of human beings. Having now such a yardstick of prognosis at hand, this has a direct bearing on the planning and implementation of rehabilitation programmes at both institutional and ficld levels: since one of every 4 or 5 patients will develop deformity, one is now in a position to forecast the average delay before its onset. 
As for the 2 polar types of leprosy, i.e. Tuberculoid and Lepromatous, it is a universally accepted rule that deformity is comparatively an early manifestation in the former, and a fairly late one in the latter. One can now predict how carly or how late this will occur. The onset of deformity can be up to three times longer among the Lepromatous than among the Tuberculoid; that deformity seems to be an earlier manifestation among the Borderline than among the Indeterminate patients; that the onset can be delayed as much as twice as long among the Indeterminate than among the Tuberculoid cases.

It now appcars that the onset of deformity is related to sex, and that men are earlier affected than women by an average of $2 \frac{1}{2}$ years. One reason for this difference may be that men are engaged in a rougher manual work, hence the greater risk of damage through pressure and trauma on the anaesthetic digits.

As for the effect of age, deformity began to appear an average of 2 years and 8 months after the start of the disease in the $\mathrm{I} I-20$ age group; an average of $5 \frac{1}{2}$ years in the $2 \mathrm{I}-3 \mathrm{O}$; an average of 6 years and 9 months in the $3 \mathrm{I}-40$; an average of 7 years and 4 months in the $4{ }^{I}-50$; an average of 9 years in the $5 \mathrm{I}$ onwards.

Yet, it is very likely that the younger patients who are becoming deformed only show their deformity when they get to a later age group. Therefore, the later age group totals include those who are becoming deformed in the earlier age groups. Taking this into account, it seems that, nevertheless, the younger the age group on the whole, the earlier tends to be the onset of deformity. On the other hand, the present study shows that deformity practically never appears before the age of 5 and that it is a pretty rare occurrence under the age of $\mathrm{I} O$.

\section{The clinical pattern of Deformity:}

In this study, $8.4 \%$ of the patients (i.e. 59 out of 700) stated that the disease began and persisted with neural disorders. This is the polyneuritic or 'pure' neural form of leprosy which belongs to the broad Tuberculoid group and which is generally in a minority. However, there is a need to differentiate it from other amyotrophic diseases, for as Freitas and Couceira ( 1939) pointed out there is sometimes difficulty in distinguishing the 'pure' form of neural leprosy from the muscular atrophy of the AranDuschenc type. Similar views were expressed by Pessin (1948). Kolb (1946), on the other hand, stressed the importance of differentiating ncural leprosy from syringomyelia, a somewhat difficult task in the early stages of both diseases (Pessin, I 948; Darma and Baruch, I95I ; Lıcas, I 956).

$89.2 \%$ of the patients with deformity of the extremities had noticed skin signs before neural disorders; $96.9 \%$ had a disturbance of sensation before motor or trophic symptons. However, the patients' own impressions may be unreliable particularly in respect of the recognition of the early stages of loss of sensation or the early stages of motor weakness. Bresani-Silva (1956-7) observed that $54.7 \%$ of his series started with neural symptoms and in $85 \%$ the disturbance of sensation appeared before the motor and trophic ones.

\section{Comparative Frequency of Deformity between Clinical Forms :}

It was observed that the deformities either of the hand or of the foot or of both hand and foot in the same individual, were more frequent in the Borderline type, and progressively less so in the Tuberculoid, Lepromatous and Indeterminate types in that order. Proportionately then, the highest incidence of deformity was seen among the Borderline, and the lowest among the Indeterminate cases. However, it must be stated that the frequency of deformity varies from one geographical region to another. Possibly this may be related to the geographical variations in the clinical types of leprosy. More information on a world-wide basis is required on this topic. Gay Prieto (196I) stated that the WHO Leprosy Advisory Team found in Northern Nigeria a deformity rate of $87.8 \%$ among the Lepromatous, $34.6 \%$ among the Indeterminate and $22.18 \%$ among Tuberculoid cases. In the Cameroons, the figures were $8 \mathrm{I} .09 \%$, $43.08 \%$ and $26.3 \%$ respectively. In both places, the number of Borderline cases were too small to permit any conclusions to be drawn. Yet Hargraves (1963) found that the percentage of disabilities held for both the Lepromatous and the Tuberculoid of his group. Jonquieres and Capurro ( 1963 ) found a low incidence of neuro-

Onset and Pattern of Deformity 85 
logical phenomenon leading to disabilities among the Borderline of their series.

\section{Comparative Frequency of Deformity and Sex:}

It was found in the present study that deformity of the hand, foot or both hand and foot in the same individual was seen slightly more often in men than in women. This is in accord with the statement of Gay Prieto ( I 96 I) to the effect that, as a rule, leprosy affects men more than women and that there is a concomitantly higher rate of disabilities among males. This was also pointed out by Guinto ( 1960 ). although both of these workers did not supply data supporting this view. Hargraves (1963) found a slight sex difference in his group. The findings of the WHO Leprosy Advisory Team in Northern Nigeria, Cameroon, Thailand and Burma pointed to a difference which was statistically not significant.

\section{Comparative Frequency of Deformity in each Age Group:}

Deformity of the hand or foot alone or of both hand and foot in the same individual followed a definite pattern: it began to appear in the I I-2O age group, was more common in the $2 \mathrm{I}-30$ age group and became progressively less thereafter. These findings do not mean that older leprosy patients have less deformity than younger ones, but that patients contract the disease in their teens or in early adult life. Gay Prieto (I96I) stated that the frequency of disabilities increases with age, but cited no statistical evidence in support of his statement. On the other hand, Martinez Dominguez and Bechelli ( I 963), following the general findings of the WHO Leprosy Advisory Team in Northern Nigeria, Cameroon and Thailand, concluded that the frequency of disabilities increases with old age by reason of the more advanced stage of the disease and the greater proportion of the Lepromatous cases among old people. This is in keeping with the results of the present study which has shown to what an extent disabilities do, in fact, increase with old age as well as decrease with it, on the plea that the majority of Borderline cases do become Lepromatous.

The WHO Leprosy Advisory Team (1965) found in their random sampling surveys that the frequency of disabilities was rather high in children of the $5^{-1} 4$ year age-group, an average of $12.6 \%$ in Cameroon, Northern Nigeria, Thailand and Burma. The same team having also found some evidence pointing to the fact that the longer the period prior to treatment, the greater the proportion of disabilities, the overall implications are clear: early treatment may to some extent prevent them, as it remains a sure and cheap way to avoid future socioeconomic difficulties and the heavy expenses of rehabilitation. It is also evident that the disability and consequently the deformity rates increase if early diagnosis and early preventive measures are not carried out, hence the need for special attention to the child and young adult populations in countries where leprosy is endemic.

\section{Nature of Deformity:}

The sequence of involvement of the digits was the same in the hand as in the foot (in the WHO classification $\mathrm{A}_{3}, \mathrm{~A}_{2}, \mathrm{~A}_{4}$, and $\mathrm{A}_{5} ; \mathrm{B}_{3}$, $\mathrm{B}_{2}, \mathrm{~B}_{4}$ and $\left.\mathrm{B}_{5}\right)$. Proportionately, claw-hand was almost as common as perforating ulcer. Partial absorption of fingers was more common than partial absorption of toes, actually in a ratio of $3: 2$. The total absorption of fingers was twice as common as the total absorption of toes. This implies that, in this series, the overall incidence of hand involvement was one and a half times as much as the foot involvement (both representing $96.2 \%$ and $65.4 \%$ of the total number of cases respectively).

In this study, the author found that it was more common for both limbs to be involved than one alone. The ratio bilateral involvement to unilateral involvement in the hand was $3: 1$ and in the foot $2 \frac{1}{2}: 1$.

Our finding that the hands were more frequently involved than the feet agrees with the one of Bresani-Silva (1956-7). This is not surprising in view of their more active functional role. What is alarming, though, is the extent to which the affected hands are neglected in leprosy. Fingers with contraction were usually allowed to develop contracture (from the reversible to the irreversible stage). Bilateral involvement was the common finding. Both of them in fact indicate sad neglect, both of them lend urgency to our problem. 
The general pattern of involvement of the affected digits and their sequence of clevelopment showed that the $5^{\text {th }}$ or little finger and ist or big toe are the first to be affected (both representing $54.4 \%$ of the affected fingers and $47.8 \%$ of the affected toes respectively): in this series, however, the little finger was twice as often and twice as early involved as the big toe. The next digits of clinical importance were the 2nd or index finger and the 2nd toe (both representing $12.8 \%$ of the affected fingers and I $5.2 \%$ of the affected toe respectively). Unfortunately, no data in the literature are available for comparison, but the inference is obvious: in the mass education of population at risk, emphasis should be laid on the involvement of the little and index fingers and the big and second toes as the earliest manifestation of deformity.

The next question, having indentified the earliest manifestation, is 'How quickly does deformity develop from one limb to the corresponding or opposite one?' In this series, an average of 2 years from hand to hand (whether from right to left or left to right); an average of $2 \frac{1}{2}$ years from foot to foot and an average of 3 years from hand to foot and foot to hand.

This study shows for the first time, as far as the author can determine, that deformity of one extremity is seldom an isolated occurrence for an indefinite period of time; on the contrary, figures show that deformity of the corresponding extremity or of the opposite one is likely to follow within 2 years from hand to hand; within $2 \frac{1}{2}$ years from foot to foot; within 3 years from upper to lower limbs and vice versa. These 2 to 3 years are ample time for preventive treatment. Seldom does such a neglected disease give such a long warning. Seldom is such a clear warning so sadly disregarded.

\section{Combined Deformity in the same Individual:}

As with deformity of upper and lower extremities, the incidence of involvement of both extremities followed similar pattern in respect of the other clinical features studied. No figures can convey the suffering expressed by the finding in this study that $58 . \%$ of the patients had combined deformity of the extremities, and $60.2 \%$ of them had involvement of both hands and both feet. These figures are a measure of the extent to which leprosy had advanced in thesc patients at the time this study was made. They are an expression in figures of measureless human suffering. The tragedy is that those results are preventable, and once more, there is a period of approximately 3 years during which effective measures of treatment could have been applied. Three years of neglect resulted in deformity of both hands and both feet in 3 out of every five patients.

The earlier part of this study has shown that for a fairly long period the striking mark of leprosy is the involvement of one digit, the little finger or the big toe. The conclusion seems inescapable: the task of leprology is to seek these early cases.

What other disease of this importance gives the physician such a long time to apply these remedies? The essential tragedy of leprosy is the tragedy of opportunities missed. This study attempts to define the problem, and establish the factual basis upon which a rational therapeutic programme can be planned.

\section{SUMMARY}

Time of Onset of Deformity of the Extremities in Leprosy:

I. A sudy of 700 cases of deformity of the extremities was carried out among a selected group of patients in Northern Burma.

2. Deformity of the extremities appeared an average of 2 years and 9 months after the start of the disease in the Tuberculoid; an average of $4 \frac{1}{2}$ years in the Borderline; an average of 5 years and 3 months in the Indeterminate and an average of 9 years in Lepromatous leprosy. Thus in this study, the onset of deformity was 3 times as long in the Lepromatous as in the Tuberculoid cases. At any rate, even when the march of disease was most rapid there was a latent interval of nearly 3 years during which treatment could have prevented deformity.

3. Men were affected at an earlier stage than women, by an average of some $2 \frac{1}{2}$ years. This was related to the fact that men are engaged in a rougher manual work at an earlier age, with thus greater risks of injury and secondary infection of the anaesthetic digits.

4. Deformity of the extremities was not seen under the age of 5 and was a rare occurrence

Onset and Pattern of Deformity 
before the age of Io. The younger the age group, the earlier seems the onsct of deformity. Whether affecting hands or feet alone or in combination, deformity of the extremities was first seen between the ages of $\mathrm{I} 1$ and 20, and most often appeared between $2 \mathrm{I}$ and 30 . 'Thereafter its incidence steadily declined with age.

5. As one in four of five patients with leprosy is likely to develop deformity, it is possible, on the strength of the present study, to predict the average delay to be expected with each clinical type, sex and different age groups. A yardstick of prognosis emerges which has its place in diagnosis, treatment and the planning of rehabilitation programmes, at both institutional and field levels.

\section{Clinical pattern of Deformity of the Extremities in} Ieprosy:

I. Frequency of Deformity between clinical Forms: It was found that deformity of the hands, feet or both followed an identical order of frequency: Borderline, Tuberculoid, Lepromatous and Indeterminate. Thus deformity of the extremities was most common in the Borderline and least common in the Indeterminate cases.

2. Frequency of Deformity per Sex: Men werc slightly more of ten affected than women.

3. Frequency of Deformity per age Group: As per paragraph 4 above.

4. Predominant Types of Deformity: Contracture, mobile claw-hand, partial absorption of fingers and total absorption of fingers in that order. In the foot: perforating ulcers, claw-tces + footdrop, partial absorption of the toes and total absorption of the toes respectively. In this study, the 2 predominant types of deformity were contracture and perforating ulcers.

5. Nature of Involvement: Bilateral involvement was much more common than unilateral involvement in a ratio of $3: \mathrm{I}$ in the hands and $2 \frac{1}{2}: I$ in the feet.

6. Incidence of Involvement: Hands were $\mathrm{I} \frac{1}{2}$ times more involved than the feet.

7. Pattern of Affected Digits: The first digits to be affected were by far the $5^{\text {th }}$ or little finger and the ist or big toe; next of clinical importance were the 2nd or index fingers and the 2nd toe.
8. Time Interval between Affected Digits: An average of 2 years from hand to hand (whether from right to left or left to right); of $2 \frac{1}{2}$ ycars from foot to foot and of 3 ycars from hand to foot and foot to hand.

\section{CONCLUSIONS}

In this study, two fundamental aspects of the natural history of the onset of deformity of the extremities in leprosy have been investigated, namely the latent interval between the start of the disease and the appearance of deformity and its pattern of development. Such data have not been collected before as far as the review of the litcrature can determin. They offer a means of predicting the course of the disease, and would appear to be fundamental to any large-scale planning of anti-leprosy campaigns as well as to institutional work.

Now that the average delay before the onset of deformity can be stated for the various clinical forms, the sex and age of the patient, and now that the march of events from digit to digit and from limb to limb is clear, the necessity for early diagnosis, early treatment and early preventive measures comes to have more weight and more than a touch of urgency, with the aim of warding off deformity is now seen to be within the limits of possibilities, with special attention to the child and young adult populations. What other similar disease offers the physician three years of grace?

This concept should encourage those engaged in treatment. It should enrich with understanding and faith those carrying out preventive measures. These data, once more, emphasize the importance of early diagnosis and early recognition of deformity. Perhaps in no other disease are the rewards of early diagnosis so rich. Perhaps in no other disease are the penalties for neglect so terrible.

Deformity is not an inescapable feature of leprosy work. It is preventable by proper measures. All those experienced in leprology are agreed that most of the disabilities in leprosy can be prevented and that those which cannot be prevented can be corrected by reconstructive surgery. The philosophical acceptance of the inevitable is an attitude which can hardly be tolerated in this day and age, when the present study shows that there is plenty of time for therapy to be carried out. 
How much is being done for the prevention of deformity, how much for rehabilitation? The author's experience in West Africa, Burma and India, has been that, whereas commendable efforts are being made to train more leprosy physiotherapists, yet there are no wide-scale programmes to prepare them nor is there a sufficient number of surgeons to cope with the demands of the situation. Hundreds of thousands of leprosy patients are the victims of disabilities, thousands more are becoming deformed, and our study has shown that these are mostly young people who could have been saved from them and still be spared unnecessary suffering.

As the members of the Panel on Physical Medicine and Rehabilitation at the International Congress of Leprology (1963) have pointed out, the greatest barrier to rehabilitation from leprosy has been difficulty of the cure of the disease. This is overcome. The second barrier is public ignorance, prejudice and fear. This will, unfortunately, be the case for years. The third great barrier is the prejudice of physical disabilities which is a matter of grave concern as it goes on after the disease is cured, thus making a return to normal life difficult even when pulslic prejudice is no more. This is preventable.

Reconstructive surgery requires both specially trained personnel as well as special equipment, neither of which fulfills the needs of rehabilitation in countries where leprosy is endemic. The heavy financial implications involved would takc years to reach all those suffering from deformity, with the result that money and manpower would be better spent in prevention.

Prevention is not only easier than correction, but is within the reach of every leprologist and para-medical worker with the minimum of training and inexpensive equipment. Time must, therefore, be found to guide and help those patients in whom they recognize the early signs of deformity. Sufficient time can be generally found in both institutions and field work for this purpose.

Yet the irony is that rehabilitation is still thought as something which starts after the disease is cured. This tragic error explains to a large extent the present bleak picture of disabilities in the world. Rehabilitation not only starts as soon as the disease is diagnosed, but persists throughout treatment and after it if necessary; if not, the intervening changes in the patient himself and prejudice among his relatives and friends may evolve into a stage when they become irreversible.

What of the future? The stigma of leprosy will fade when public and patients alike accept the disease as any other disease, but unlike many is eminently curable. It lies when full information will be obtained on the frequency and degree of disabilities world-wide so as to have a true picture of the socio-economic implications of leprosy, hence a better idea will be obtained as to the most effective planning of preventive and corrective measures.

The future lies in the cultivation in vitro of M.leprae, in the clearer understanding of the pathogenesis of the disease, in research and perhaps in the avoidance of the word 'leper', and in substituting Hansen's disease for Microbacterial Neuropathic Dermatosis (M.N.D.) proposed by Ross Innes ( 1963 ) or for Hansenosis suggested by Goldman ( 1963 ) instead of leprosy, though, as Skinsnes (1964) rightly remarked, it is questionable whether such a laudable purpose can be achieved in view of the pattern of society's deeply-ronted reactions and hence the wisdom of leaving the word leprosy as such so as to allow a gradual decline of the misconceptions and musunderstandings attached to the disease on its time-honoured scale.

The future lies in a widerstudy of leprosy with increasing contributions from the allied branches of medicine, for as Loginov ( 1964 ) pointed out, there is still a great deal of obscurity in the theory and practice of leprology, and that the majority of the unanswered questions are closely bound up with the present-day problems of medicine and biology.

The future finally lies in the leprosy rehabilitation services when they will be fully integrated with other rehabilitation programmes in general hospitals and other institutions, hence the vital importance to pave the way, however long, for it in countries where the fight against leprosy is to be guided still along proper lines.

The attitude of society and of other medical and scientific disciplines towards the leprosy patient depends not only on education, but upon the belief in the individual worth of every human being. A lot is achieved when curing a 
leprosy patient, but by preventing deformity we do prevent the loss of a man's self-respect, of his dignity. 'Homo sum, humani nihil a me alienum puto?' This study attempts to show that this prevention is well within our reach.

\section{ACKNOWLEDGEMENTS}

The author wishes to express his gratitude to: The field staff of Shwebo and Monywa, Upper Burma, for making the necessary arrangements for his stay in the various villages. The Reverend Mother Superior and Staff of the St. John's Leprosy Asylum, Mandalay, for facilitating his work among the in-patients. Professor Paul Brand, F.R.C.s., lately of the Vellore Medical College, South India, and Mr. J. P. Blandy, M.A., D.m., ch.m., F.R.c.s., Epping, Essex, U.K., for thcir helpful criticisms.

\section{REFERENCES}

andersen, J. G. ( I 96 I ) Lep. Rev. 32, I 6-27.

- ( 1962) .7. Ch. Med. Ass. Ind. 36, I-6.

- ( 1962 ) Lep. Ind. 34, I I6-I 2 I .

argenta, G. ( I 96 I) Ed. Calia di Napoli. Abstracts.

Banedoch, A. G. and byron, F. R. (1932) Med. Trop. \& Hyg. 26, 253-258.

BANG, T. v. and DIEP, N. D. (1958) Symposium paper, Int. Cong. Lep. Tokyo.

barnetson, J. (i 95 I) Int. F. Lep. r9, 297-307.

- (1950) Acta. Rad. 34, 35-64.

- (1950) Trans. Roy. Soc. Trop. Med. \& Hyg. 43, 535- 538.

- (1950) Idem. 539-544.

basset, A. and schneider, g. (i950) Bul. Soc. Fr. Derm. \& Syph. 57, 299-302.

B $\Lambda \mathrm{su}$, s. P. ct al (1961) The Lic. Ambala. ro, 369-378.

branis, p. w. (1958) Leprosy in Theory and Practice, Cihapter XXI.

- (1958) Symposium paper, Int. Cong. Iep. 'Tokyo.

- (1959) Int. 7. Lep. 27, I-7.

- (1 963) Rehab. Lit. 21, 238-245.

- (r 964) Personal communication.

bresani-silva, f. ( i 956) I. Rev. Per. de Salud Pub. Lima. 5, 79-204.

- ( 1956$)$ II. Idem. 5, 229-340.

- (1956) III. Idem. 5, 379-50 I.

- ( 1957 ) IV. Idem. 6, I-I 6.

Carayon, A. and huet, R. (1958) Trop. Dis. Bul. r, 54-55.

Casacci, A. (1 950) Clin. Orth. 2, 37-52.

chardome, J. and lechat, m. (1955) Ann. Soc. Belge Med.

Trop. 35, 267-278.

- (1958) Symposium paper, Int. Cong. Lep. Tokyo.

ChatterJee, s. N. ( I 955) Int. 7. Lep. 26, I-I 7.

- ( 1964$)$ Idem. 4: 384-409.

Chaussinand, R. (1950) L Lèpre. Exp. Sc. Fr. Paris.

Cherlinzoni, c. and piratsu, E. (1952) Chir. Organi Mov.

37, I I 6-I 33 .

COONEY, J. P. and CROSBY, E. H. (1944) Rad.42, 9-1 4 . cuervo, J. м. ct al (1944) Rev. Lep. Derm. y Sifil. Guba. I, 148.

Darmar, h. and baruth, s. (I95 I) Conlr. Clin. Sc. Istanbul. I, $478-97$

Da Veiga, s. ( I 947) Ann. Inst. Med. Trop. Lisbon, 4, i 49-6o.

dharmendra, c. (i 960$)$ Notes on Lep. Mins. Hlth. Delhi. $57-65$.

DHOPle, A. M. and MAGAR, N. G. (1962) Lep. Ind. 4, 299-305. DOUll, J. A. (1959) Int. 7. Lep. 27, 202-2 I 5 .

- (1963) Presidential address, cibA Fd. Symp. Path. Lep., London

Dubois, A. (I 95I) Ann. Soc. Belge Med. Trop. 31, 525-529). - and RADERMECKer, m. A. (1953) Int. J. Lep. 2I, 204-2 I 7. EDWARDS, R. H. T. (1964) Lcp. Rcv. 35, 3-13.

ERickson, P. T. and JOHANSEN, F. A. (I948) Int. 7. Lep. I6, I 47-I 56 .

- and Mayoral, A. (1950) Rad. 54, 357-364.

esquerra-gomez, G. and Acosta, E. (I948) Rad. 50, 6i9638.

FAGET, G. H. and MAYORAi., A. (I944) Rad.5o, 6r9-638.

FITE, G. L. (I94I) Int. 7. Lep. 9, I 93-202.

and virgilio, s. (1942) Rev. Bras. Lep. 10, 273-302.

freitAs, J. O. and couceiro, A. (i939) Rev. Bras. Lep). 7, 97-1 20.

G $\Lambda$ Y PRIETO, J. (I 958) Int. J. Lcp. 26, $44 \mathrm{I}-446$.

- (I96I) WHO Series, WPR/LEP/20, I-IO.

GLYN Griffiths (i 964 ) Personal communication.

Goldman, L. (1963) Lep. Rev. 35, 51-52.

Guinto, R. ( 1 960) Prof erred paper at the Scientific Meeting on Rehab. in Lep., Vellore, Ind.

hargraves, J. (1963) Med. 7. Australia 2, 225-227.

IMAEDA, T. (I 968) I \& II. La Lepro, 27, I-25.

JONQUIERES, E. D. L. and CAPURRO, E. T. (1963) Leprologia, 8, $48-49$.

KADRINKA, s. and merdjo, A. (I 938) Rad. 7, 269-286. kARASEFf, J. (I 936) J. Rad. \& Electrol. 2o, 373-382.

кAтsumi, н. (i 955) I \& II. La Lepro, 24, 78-96.

K'UNG C'HING-TEH et al ( I 959) Ch. Med.7. 79, I 30-I 37.

languillon, J. and Boissan, R. (i959) Med. Trop. i9, $55^{8}-567$.

- (1960) Idem. 2o, 432-492.

- and carayon, a. (I 16 I) Sup. P'resse MIed.69, i-.1.

Lechat, м. (1960) Etudes des Mutilations I.ípreuses. I 7-I 77.

- (1962) Int. 7. Lep. 30, I 25-1 37.

- and chardome, J. (1957P Ann. Soc. Be!ge Mec. Trop. 37: $907-918$.

- et al ( I 96 I ) Idem, 4r, 535-566.

- et al (1961) 7. Chir. Dis. St-Louis, 13: 22 1-227.

LENNOx, w. M. (1 964) Lep. Rev. 35, 245-249.

LINDUI and Ross (I 957) cited by Lechat ( I 960).

LOGinov, v. K. (1964) Lep. Rev. 35, I 4-20.

LUCAS, C. J. (1956) B.M.7. 2, 214.

MAllac, M. J. (i 96o) Lep. Rev. 31, I 2-1 8.

- (I 962) WHO/SEARO/LEP/II, I-I 4 .

- (I 963) WHO/SEARO/LEP/I 7, I-9.

- (1 964$)$ WHO/SEARO/LEP/I 9, I-I 6.

MARTINEZ-DOMingueZ, v. M. and Becheli, L. M. (I963)

Proferred paper at the In t. Cong. Lep. Rio.

mathur, J. s. and saxena, K. N. (1965) Lep. Rev. 36, 77-8I. mille, R. and PAPA, F. (1961) Arch. past. Martinique, 14, 24-29.

minato, J. ( 1958) Int. 7. Lep. 26, $442-448$. 
montestruc, E. (1960) Arch. Past. Martinique, 13, 90-98.

- and hydrominus, J. c. (1961) Bul. Soc. Path. Exot. 54, 988-995.

MUELling, R. J. et al (i 96o) Int. 7. Lep. 28, i 44-1 54 .

murdoch, J. R. and hutter, h. J. (i932) Am. J. Roentg. 28, $589-598$.

MUT mUt, т. (1953) Int. J. Lep. 21 , 6 i $5-623$.

NÉGRE, A. and fontan, R. (i957) Trop. Ned. Bul. 54 $579-586$.

NishikAWA, T. (1934) Int. J. Lep. 2, 487-492.

NisHiURA, M. (I 955) La Lepro, 24, 204-2 I 5.

oberdorffer, M. J. and Collier, D. R. (i940) $4 \mathrm{~m}$. J. Roentg. 44: 386-395.

PATERSON, D. E. (1955) 7. Fac. Rad. 7: 35-36.

- (1956) Int. 7. Lep. 10, 90-97.

- (1 958) Leprosy in Theory and Practice. Chapter XX.

- ( 1 96 I ) Int. 7. Lep. 29, 397-422.

pessin, J. (1 948) Arch. Neur. EO Pschy. 6o, 288-296.

radermecker, m. A. (1952) Acta. Neur. \& Pschy. Belge; 52, 204-217.

Report of the Panel on Epidemiology \& Control (1963) Int. Cong. Lep. Lep). Rev. 2, I 7-33.

- Physical Med. \& Rehab. (1963) Idem. 43-51.

— Ld. \& Soc. Aspects (1963) Idem. 52-72.
Ross, SR. H. ( 1955) Len. Wood Mem. 6, 2 I-23.

- (1955) Idem. 26-47.

SKINSNES, O. K. (1964) I. Lep. Rev. 35, 2 I-35.

- (1965) III. Idem. I 75-18 I.

susman, i. A. (1 963) Lep. Rev. 2, 83-94.

torsuyeva, n. N. (1962) Col!. Sc. Paper on Lep. \& Derm. 16, 86-89.

VENKATASUBRAMANian (I94I) cited by Ross (I955).

wayson, n. e. and Badger, L. F. (1929) Pub. Hlth. Bul. USA. 189, I 6-42.

W.H.O. Tech. Rep. Series (1960) International Work in Leprosy.

- (I960) Scientific Meeting on Rehabilitation in Lcprosy.

- (1960) Disabilities due to Leprosy: Extent of the Problem.

- (1965) A Review of the Jointly Assisted Leprosy Control Projects, UNICEF/WHO Joint Committee on Health.

wooley, J. g. (1931) Pub. Health Rep. USA. 46, 641-658. - and Ross, sR. H. (1932) Idem. 47, 380-389.

wozonig, H. (1958) Trop. Dis. Bul.54, 699-7o6. 